\title{
Kobieta z zespołem Turnera na rynku pracy
}

\author{
A Woman with Turner Syndrome in the Job Market
}

\section{Streszczenie:}

Niniejszy artykuł poświęcony jest sytuacji kobiet z zespołem Turnera na rynku pracy. Pacjentki, o których mowa, dotknięte są schorzeniem genetycznym, prowadzącym do niskorosłości, bezpłodności, wad narządów wewnętrznych oraz tendencji do zapadania na liczne choroby przewlekłe. Codzienne funkcjonowanie kobiet z ZT w żaden sposób nie różni się od funkcjonowania kobiet o prawidłowym kariotypie, choć bezpłodność i choroby towarzyszące mają wpływ na różne aspekty ich życia. Potencjalnie mogą one doświadczać dwojakiej formy dyskryminacji w swoim miejscu pracy ze względu na płeć i ze względu na niepełnosprawność. Przebadano 14 dorosłych kobiet z zespołem Turnera. Zaproponowany kwestionariusz ankiety zawierał pytania dotyczące stanu zdrowia i historii leczenia, sytuacji rodzinnej, ścieżki edukacyjnej oraz doświadczeń na polu zawodowym. Załączono również rekomendacje do wdrożenia w środowisku kobiet z ZT w celu kształtowania dobrych praktyk.

Słowa kluczowe: zespół Turnera, rynek pracy, niskorosłość, praca kobiet, praca osób z niepełnosprawnością

\begin{abstract}
:
The article is about the situation of women with Turner Syndrome in the job market. The patients are suffering from a genetic disorder that leads to short stature, infertility, organ malformation and higher risk of many long-term diseases. The daily functioning of TS women does not differ from the functioning of women with a normal karyotype, though it is true that infertility and health problems do affect many aspects of their lives. Potentially they may experience the two types of discrimination in their working place - discrimination against women and discrimination against people with disabilities. The research engaged 14 adult women with TS. The question-
\end{abstract}


Katarzyna Waliczek - Kobieta z zespołem Turnera...

naire included questions about health history, family situation, education and career experience. The recommendations for good practices were also included.

Keywords: Turner syndrome, job market, short stature, women at work, persons with disabilities at work

\section{Wprowadzenie}

Kobiety z zespołem Turnera doświadczają wielu problemów zdrowotnych, głównie hormonalnych, jednak w większości przypadków nie zaburza to ich codziennego funkcjonowania i mogą podjąć pracę zawodową. Na współczesnym rynku pracy spotykamy się z różnego rodzaju formami dyskryminacji - mówi się $\mathrm{m}$. in. o dyskryminacji ze względu na płeć czy niepełnosprawność. Czy kobiety z zespołem Turnera doświadczają takich negatywnych sytuacji w miejscu pracy? Jak postrzegają swój stan zdrowia oraz swoją karierę edukacyjną i zawodową? W artykule przedstawiono wyniki ankiety przeprowadzonej na grupie 14 dorosłych pacjentek z monosomią chromosomu X, a także rekomendacje mogące stanowić preludium do wprowadzenia dobrych praktyk.

\section{Zespół Turnera jako jedna z przyczyn niepełnosprawności u kobiet}

Zespół Turnera jest to jedna $\mathrm{z}$ aberracji chromosomowych, polegająca na braku lub uszkodzeniu jednego $\mathrm{z}$ chromosomów $\mathrm{X}$ u zarodka płci żeńskiej. Charakterystycznymi objawami zespołu są niskorosłość (pomimo prawidłowego poziomu hormonu wzrostu w organizmie) oraz niedorozwój jajników objawiający się opóźnionym dojrzewaniem płciowym, niedoborem estrogenów wraz ze wszelkimi konsekwencjami oraz bezpłodnością1. U pacjentek często stwierdza się wadę serca, nieprawidłowości w budowie nerek, niedoczynność tarczycy,

\footnotetext{
1 Por. K. Łącka, Zespół Turnera - korelacja między kariotypem a fenotypem, „Endokrynologia Polska" 2005, tom 56, nr 6, s. 987-988.
} 
tendencję do cukrzycy typu II oraz osteopenii (odwapnienie kości), a także problemy ze słuchem (najczęściej spowodowane nawracającym zapaleniem ucha) lub ze wzrokiem.

Należy podkreślić, że rozwój umysłowy kobiet z zespołem Turnera przebiega zgodnie z normą - niepełnosprawność intelektualna dotyka jedynie $5 \% \mathrm{z}$ nich ${ }^{2}$. U dziewczynek z ZT na testach inteligencji często da się zauważyć charakterystyczny profil umysłowy, to znaczy dominację inteligencji słownej nad bezsłowną. Uczennice często wykazują szczególne zdolności na lekcjach języka polskiego oraz języków obcych. Z drugiej strony, mogą się u nich pojawić trudności w nauce matematyki lub objawy świadczące o dysleksji³.

Zespół Turnera może więc prowadzić do niepełnosprawności z kilku przyczyn. Pierwszą z nich jest niskorosłość - swoista odmiana niepełnosprawności ruchowej. Przyjmuje się, że średni wzrost dorosłej kobiety z ZT nieleczonej hormonem wzrostu to $143 \mathrm{~cm}^{4}$ - dla porównania, organizacja Little People Of America, zrzeszająca osoby $\mathrm{z}$ achondroplazją i niskorosłe $\mathrm{z}$ innych przyczyn, za osobę niskorosłą uważa osobę dorosłą o wzroście równym lub poniżej 4 stóp i 10 cali, co daje $147 \mathrm{~cm}^{5}$. Pacjentki leczone hormonalnie w okresie dzieciństwa i / lub adolescencji nie różnią się wzrostem od kobiet zdrowych. Część kobiet z ZT wymaga opieki ortopedycznej (nieprawidłowości w budowie układu kostnego, odwapnienie kości).

Kolejnym rodzajem niepełnosprawności, który może dotknąć dziewczynę z monosomią chromosomu $\mathrm{X}$, jest choroba przewlekła. Najczęstsze schorzenia towarzyszące ZT to wada serca i niedoczynność tarczycy. W zależności od rodzaju problemu pacjentka będzie wymagać leczenia farmakologicznego, zabiegów chirurgicznych, diety

\footnotetext{
2 Por. ibidem, s. 990.

3 Por. I. Zadrożna, Zespół Turnera, [w:] M. Buchnat i K. Pawelczak (red.), Nieznane? Poznane. Zaburzenia rozwojowe u dzieci z rzadkimi zaburzeniami genetycznymi i wadami wrodzonymi, Poznań 2011, s. 123-126.

${ }^{4}$ Por. K. Łącka, Zespół Tunera - korelacja..., op. cit., s. 988.

5 Por. Little People of America, FAQ, http://www.lpaonline.org/faq-\#Operation, [dostęp: 14-04-2018].
} 
Katarzyna Waliczek - Kobieta z zespołem Turnera...

lub rehabilitacji. Może to mieć wpływ na jej funkcjonowanie w środowisku pracy (częstsze przerwy, unikanie stresu lub wysiłku fizycznego, nieobecność w pracy z powodu pobytu w szpitalu).

Kobiety z monosomią chromosomu X, choć zwykle rodzą się jako słyszące i widzące, często w późniejszym okresie życia doświadczają problemów ze słuchem lub wzrokiem. Szczególnie groźne są nawracające zapalenia uszu, które pojawiają się w dzieciństwie i prowadzą do niedosłuchu. Wiele pacjentek na pewnym etapie wymaga opieki laryngologicznej lub chirurgicznej (drenaż uszu), a w razie pojawienia się wady słuchu - audiologicznej (aparat słuchowy).

W przypadku pacjentek z ZT warto pamiętać o higienie zdrowia psychicznego. Problemy emocjonalne, jakie mogą łączyć się z monosomią chromosomu X, to: brak akceptacji diagnozy, brak akceptacji bezpłodności, brak akceptacji własnego ciała, trudności z osiągnięciem społecznego statusu „osoby dorosłej” z powodu „niedojrzałego” wyglądu (niski wzrost, słabo rozwinięte piersi, słabo zaznaczona talia), trudności $\mathrm{w}$ relacjach $\mathrm{z}$ mężczyznami (strach przed poinformowaniem potencjalnego partnera o bezpłodności), wahania nastrojów spowodowane zaburzeniami hormonalnymi (niedobór estrogenów, efekty uboczne terapii estrogenowej, niedoczynność tarczycy), w końcu strach związany z pogarszającym się wraz z wiekiem stanem zdrowia (ryzyko wystąpienia cukrzycy, osteoporozy lub innych schorzeń, których wcześniej nie było). Brak odpowiedniego wsparcia u szczególnie wrażliwych dziewcząt będzie prowadzić do stanów depresyjnych i lękowych. Oczywiście, nie dotyczy to wszystkich kobiet z tą przypadłością - generalizowanie byłoby nieuprawnione. Należy raczej stwierdzić, że profilaktyka depresji oraz higiena zdrowia psychicznego to sprawa ważna w przypadku każdej osoby z niepełnosprawnością szczególnie zaś, gdy niepełnosprawność łączy się z bezpłodnością.

Doświadczenie niepełnosprawności może także prowadzić do odkrycia specyficznych zdolności i predyspozycji zawodowych. Jak pisze Ilona Zadrożna, typową cechą przy ZT są zdolności językowe, co może 
prowadzić do wyboru studiów filologicznych ${ }^{6}$. Maria ŚwiątkiewiczMośny podaje, że dziewczyny z ZT posiadają duży poziom empatii, stąd często odnajdują się w zawodach pedagogicznych i medycznych ${ }^{7}$.

W swoim artykule z 2004 roku Joanne Rovet stwierdza, że kobiety z zespołem Turnera charakteryzują się specyficznym profilem poznawczym. Mają obniżone wyniki na testach inteligencji bezsłownej (wykonawczej), problemy z myśleniem przestrzennym, arytmetyką, pamięcią krótkotrwałą, rozpoznawaniem twarzy oraz odczytywaniem emocji po wyrazie twarzy. Mają natomiast dobrze rozwinięte słownictwo (może wystąpić utrudniona artykulacja lub problemy z płynnością mowy) i dobrze radzą sobie z czytaniem. Autorka zauważa, że pacjentki często wybierają zawody związane z opieką nad dziećmi w obszarze edukacji lub nauk medycznych, gdzie mogą liczyć na przeciętne wynagrodzenie. Około 5\% wykonuje zawody uważane za prestiżowe, wysokopłatne i/lub wymagające wieloletnich studiów, takie jak lekarz czy prawnik. Rovet zwraca uwagę także na fakt, iż większość badanych po osiągnięciu pełnoletności nie opuszcza domu rodzinnego, doświadczając problemów z osiągnięciem pełnej samodzielności, autonomii i dojrzałości społecznej.

Ilona Zadrożna, na podstawie badań z roku 2009 przeprowadzonych na grupie 30 Polek i 41 pacjentek z krajów anglojęzycznych ze stwierdzoną monosomią X, stwierdza wysoką aktywność zawodową wśród kobiet z ZT. Deklarowane relacje z rodzicami i rodzeństwem są zażyłe, często oparte na postawie nadmiernie ochraniającej ${ }^{9}$. Doświadczają trudności przy zakładaniu rodziny - większość osób badanych przyznaje, że nie posiada partnera. Gdy chodzi o kryteria wyboru

\footnotetext{
6 Por. I. Zadrożna, Zespół Tunera..., op. cit., s. 125.

7 Por. M. Świątkiewicz-Mośny, Tożsamość napiętnowana. Socjologiczne studium mechanizmów stygmatyzacji $i$ autostygmatyzacji na przykładzie kobiet z zespołem Turnera, Nomos 2010, s. 148.

8 Por. J. Rovet, Turner Syndrome: a Review of Genetic and Hormonal Influences on Neuropsychological Functioning, „Child Neuropsychology” 2004, Vol. 10, No 4, s. 265268.

99 Por. I. Zadrożna, Social Functioning of Women with Turner Syndrome. Research \& Discussion, „Interdyscyplinarne Konteksty Pedagogiki Specjalnej” 2013, nr 1, s. 124.
} 
Katarzyna Waliczek - Kobieta z zespołem Turnera...

partnera, przede wszystkim szukają osoby, która będzie je akceptować. Ich postawa w związku bywa ambiwalentna, niepewna ${ }^{10}$. Kobiety, które przeszły terapię hormonalną oraz te o niższym BMI, spotykają się z większą akceptacją społeczną $\mathrm{w}$ porównaniu do pacjentek nieleczonych lub zmagających się z nadwagą.

Według Ilony Zadrożnej 60\% badanych kobiet z ZT pracuje zawodowo. Jedna trzecia ankietowanych Polek ze zdiagnozowaną monosomią X w 2009 roku nie miało pracy - w krajach zachodnich odsetek zatrudnionych $\mathrm{w}$ tej grupie był wyższy. Pacjentki przyjmujące hormonalną terapię zastępczą, jak stwierdzono, mają lepszą sytuację na rynku pracy. Kobiety nieleczone deklarują bliższe i mniej formalne relacje ze współpracownikami, wykazują jednak większe trudności w życiu społecznym poza miejscem zatrudnienia ${ }^{11}$.

Wacław Jeż wraz ze współpracownikami przeprowadził dwa badania - jedno na grupie 112 pacjentek w latach 1995-199712 oraz drugie na grupie 176 pacjentek w latach 2007-200813. Wyniki z lat dziewięćdziesiątych XX wieku wykazały, że 6\% kobiet z ZT miało wykształcenie wyższe, 55\% mogło się pochwalić wykształceniem średnim, 28\% zawodowym, natomiast $10 \%$ miało wykształceniem podstawowe. Wśród badanych była 1 osoba wymagająca kształcenia specjalnego ze względu na powikłania po urazie okołoporodowym. Jeśli chodzi o zawód, $27 \%$ nie posiadało konkretnego zawodu, 38\% wybrało pracę fizyczną, a $35 \%$ pracę umysłową. $32 \%$ ankietowanych było zatrudnionych, $14 \%$ pobierało rentę, a $12 \%$ miało status osoby bezrobotnej.

Spośród 176 kobiet z ZT przebadanych przez Wacława Jeża w latach 2005-2008, wykształcenie wyższe miało 6\%, średnie 46\%, zawodowe 25\%, podstawowe 21\%. Nadal kształciło się 15\% ankietowanych. Pacjentki posiadające zawód najczęściej zajmowały się ekonomią, krawiectwem, kucharstwem, były też pielęgniarkami, nauczycielkami i sprzedawczyniami. Podobne zawody wykonywały matki osób

\footnotetext{
10 Por. ibidem, s. 125-126.

11 Por. ibidem, s. 128-129.

12 Por. W. Jeż i in., Zespół Turnera, Poznań 2010, s. 80-81.

13 Por. ibidem, s. 82-83.
} 
badanych - matki i córki zwykle miały też podobny poziom wykształcenia. 19\% kobiet $\mathrm{z}$ monosomią $\mathrm{X}$ było zatrudnionych na otwartym rynku pracy, $1 \%$ posiadało zatrudnienie w warunkach chronionych, $10 \%$ było bezrobotnych, jedna osoba badana była na rencie, dwie na zasiłku i jedna była pod opieką MOPS. Tutaj również Wacława Jeż wspomina o 39\% uczących się - w innym miejscu tego samego omówienia badań z lat 2005-2007 autor mówił o 15\%.

W swojej monografii Wacława Jeż i współpracownicy cytują także badania z roku 2004, gdzie przebadano 102 pacjentki. Wśród nich 46 pracowało w pełnym wymiarze, 7 było bezrobotnych, a 4 pobierały zasiłek. Gdy chodzi o sytuację mieszkaniową, 70 ankietowanych mieszkało z rodzicami, $18 \mathrm{z}$ osobami innymi niż rodzice (na przykład z małżonkiem), a 14 żyło samotnie.

\section{Wyniki ankiety}

\subsection{Informacje na temat grupy badanej}

Ankieta została przeprowadzona wśród 14 dorosłych kobiet z zespołem Turnera, skupionych wokół grupy wsparcia Zespół Turnera niezwykłe dziewczynki, kobiety w serwisie Facebook. Grupa zrzesza dorosłe pacjentki i matki dziewczynek z monosomią X, w tym kobiety oczekujące na narodziny córki z zespołem.

Wśród badanej grupy najliczniej reprezentowaną grupą wiekową były młode kobiety pomiędzy 25 a 34 rokiem życia (35,7\%). Tylko jedna ankietowana kobieta ukończyła 55 rok życia (Wykres 1).

Wśród kobiet powyżej 25 roku życia większość ( 9 ankietowanych) posiadała wykształcenie wyższe magisterskie, jedna osoba badana uzyskała wykształcenie średnie techniczne i jedna - wykształcenie zawodowe. Wykres 2 przedstawia strukturę badanych kobiet ze względu na uzyskane wykształcenie, $\mathrm{z}$ uwzględnieniem badanych poniżej 25 roku życia (3 osoby, z czego dwie uzyskały wykształcenie średnie, a jedna ukończyła studia I stopnia). 
Wykres 1. Struktura badanych kobiet ze względu na wiek

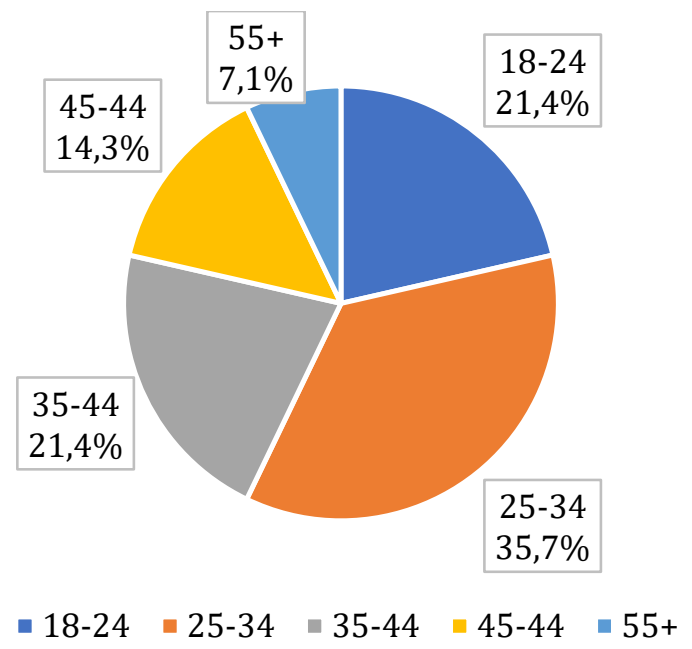

Źródło: opracowanie własne na podstawie wyników ankiety

Wykres 2. Struktura badanych kobiet ze względu na wykształcenie

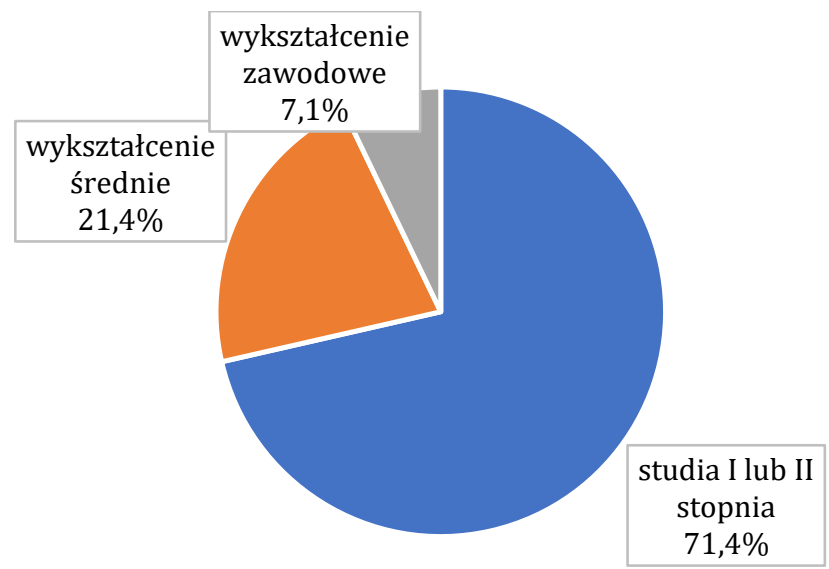

- studia I lub II stopnia " wykształcenie średnie " wykształcenie zawodowe

Źródło: opracowanie własne na podstawie wyników ankiety 
Jak przedstawia się sytuacja zawodowa osób badanych? Uzyskane dane są optymistyczne. Zdecydowana większość (9 badanych, co stanowi 64,3\%) pracuje na umowę o pracę - wśród nich jedna stara się aktualnie o rentę. Trzy osoby (co stanowi 21,4\%), z najmłodszej grupy, wciąż się uczą, natomiast najstarsza ankietowana jest emerytką. Jedna $\mathrm{z}$ kobiet musiała czasowo zrezygnować $\mathrm{z}$ pracy zawodowej ze względu na konieczność opieki nad dzieckiem.

Wykres 3. Struktura badanych kobiet ze względu na status na rynku pracy

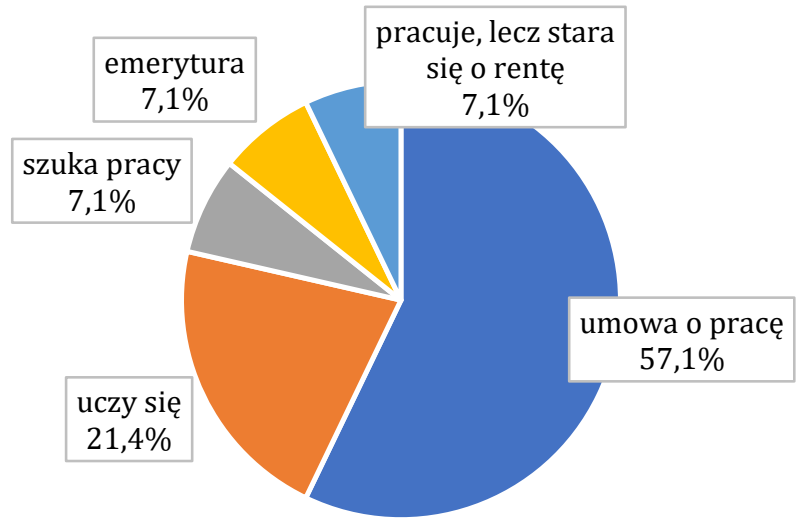

- umowa o pracę " uczy się " szuka pracy $\|$ emerytura " pracuje, lecz stara się o rentę

Źródło: opracowanie własne na podstawie wyników ankiety

Spośród czternastu ankietowanych kobiet trzy wstąpiły w związek małżeński, a cztery kolejne spotykają się z kimś (Wykres 4). Połowa badanych to singielki. W badanej grupie nie było wdów ani kobiet po rozwodzie. 
Wykres 4. Struktura badanych kobiet ze względu na stan cywilny

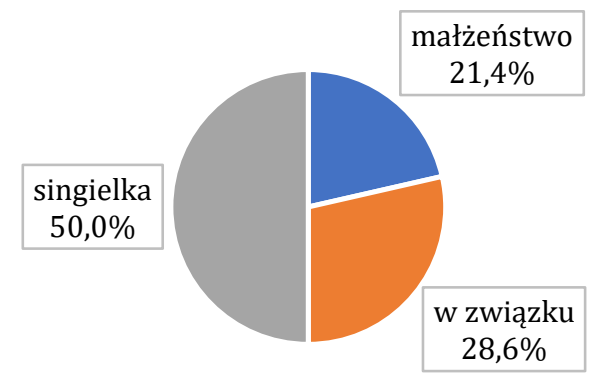

- małżeństwo " w związku " singielka

Źródło: opracowanie własne na podstawie wyników ankiety

W ankiecie zapytano także o orzeczony stopień niepełnosprawności. Ponad 40\% badanych kobiet posiada orzeczenie o umiarkowanym stopniu niepełnosprawności, a 14,3\% - o stopniu lekkim. 6 ankietowanych w ogóle nie posiada orzeczonego stopnia niepełnosprawności (Wykres 5).

Wykres 5. Struktura badanych kobiet ze względu na orzeczony stopień niepełnosprawności

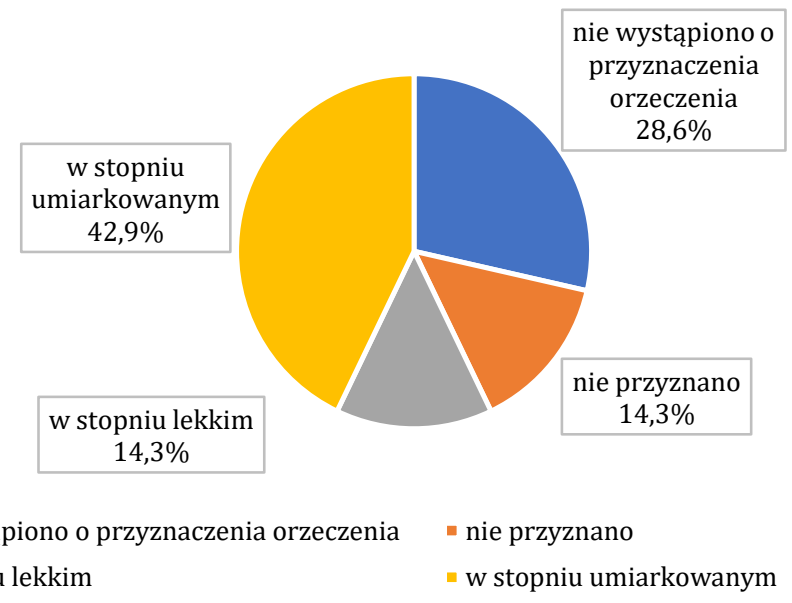

Źródło: opracowanie własne na podstawie wyników ankiety 


\subsection{Wpływ wzrostu i stanu zdrowia na karierę edukacyjng i zawodowa badanych}

Przy zespole Turnera częstym problemem są późne diagnozy. Charakterystyczne objawy tej aberracji chromosomowej stają się widoczne w okresie późnego dzieciństwa - wtedy też najczęściej rodzice zostają skierowani do poradni endokrynologicznej i genetycznej. Dziś, w dobie badań prenatalnych, coraz więcej dziewczynek jest diagnozowanych przed narodzinami. Zgodnie $\mathrm{z}$ oficjalnymi danymi w roku $2016 \mathrm{w}$ polskich szpitalach dokonano 18 aborcji ze względu na podejrzenie ZT u płodu ${ }^{14}$. Wczesna diagnoza ZT z jednej strony może zapewnić dziewczynce lepszą opiekę w okresie niemowlęcym (badania pod kątem wad narządów wewnętrznych, wczesne wspomaganie rozwoju) i przedszkolnym (kontrola słuchu, wzroku, opieka kardiologiczna, badanie poziomu glukozy we krwi i hormonów tarczycy, diagnoza pod kątem zaburzeń dyslektycznych, w końcu - wprowadzenie terapii hormonem wzrostu), z drugiej - często staje się dla rodziców podstawą do przerwania ciąży.

W badanej grupie znajdowały się kobiety urodzone przed rokiem 2000. Żadna z nich nie została zdiagnozowana przed narodzinami, a tylko jedna otrzymała wynik kariotypu przed wejściem w wiek przedszkolny. Trzy kolejne zostały zdiagnozowane przed ukończeniem 10 roku życia. Zdecydowana większość dowiedziała się o zespole po 10 roku życia, z czego dwie - po ukończeniu 21 roku życia (co należy uznać za diagnozę skrajnie późną).

\footnotetext{
14 Por. tabelka z MZ opublikowana przez Fundację Pro, http://stopaborcji.pl/ dane-z-ministerstwa-zdrowia-potwierdzaja-ponad-37-aborcji-to-dzieci-z-zespolemdowna/ [dostęp: 14-04-2018].
} 
Wykres 6. Struktura badanych kobiet ze względu na wiek diagnozy

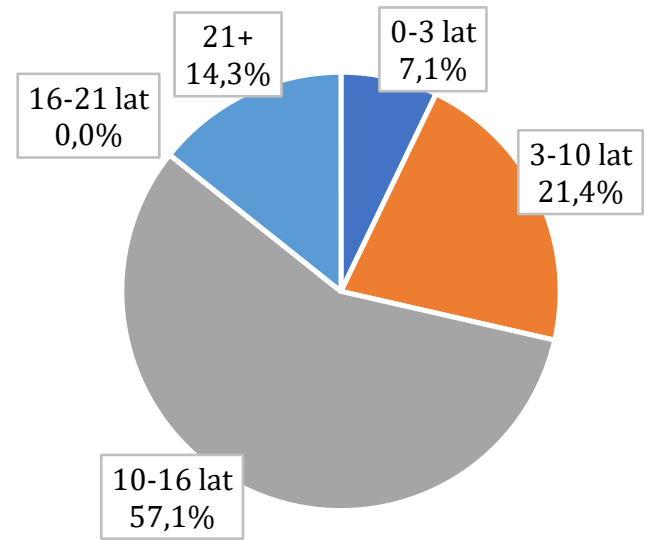

$$
\text { -0-3 lat }-3-10 \text { lat } \square \text { 10-16 lat } \square 16-21 \text { lat }=21+
$$

Źródło: opracowanie własne na podstawie wyników ankiety

Wykres 7. Struktura badanych kobiet ze względu na wzrost

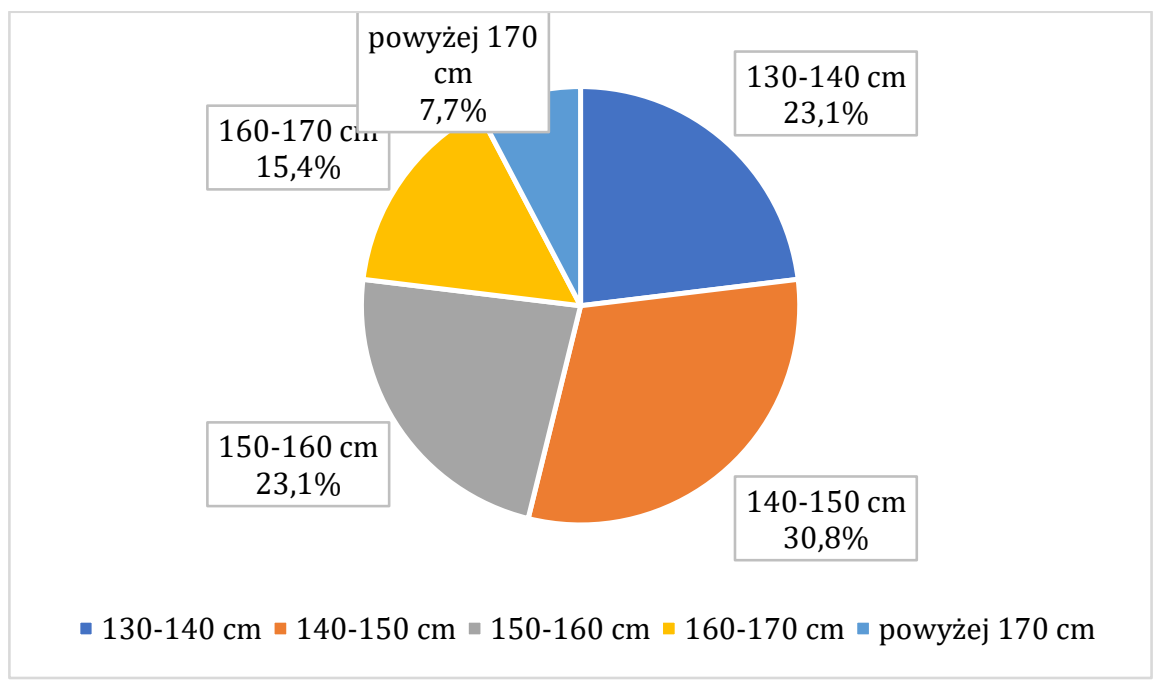

Źródło: opracowanie własne na podstawie wyników ankiety 
Późne diagnozy, w połączeniu z sytuacją gospodarczą kraju i brakiem odpowiednich regulacji w zakresie uzyskania refundacji terapii, spowodowały, że 8 pacjentek nigdy nie było leczonych hormonem wzrostu. Wśród badanych połowa jest niskorosła - ma $150 \mathrm{~cm}$ wzrostu lub mniej. W tej grupie trzy badane kobiety nie osiągnęły $140 \mathrm{~cm}$. Wzrost powyżej $160 \mathrm{~cm}$ uzyskały 3 ankietowane, z czego jedna przekroczyła $170 \mathrm{~cm}$ wzrostu (Wykres 7). Gdy chodzi o hormonalną terapię zastępczą, sytuacja przedstawia się trochę lepiej - 10 ankietowanych bierze estrogeny lub estrogeny w połączeniu z progesteronem w postaci tabletek lub plastrów.

$\mathrm{Z}$ jakimi problemami zdrowotnymi lub rodzajami niepełnosprawności poza niskorosłością i bezpłodnością musiały zmierzyć się ankietowane? Na podstawie przeprowadzonego badania stwierdzono 9 przypadków wad wzroku i słuchu różnego stopnia, z czego 5 badanych ma problemy zarówno ze wzrokiem, jak i słuchem. Połowa kobiet cierpi na niedoczynność tarczycy. Aż 6 leczyło się farmakologicznie lub jest $\mathrm{w}$ trakcie leczenia $\mathrm{z}$ powodu depresji. Wyniki mogą sugerować, że zaburzenia nastroju mogą być problemem bardziej powszechnym wśród kobiet z ZT, niż typowe dla tego zespołu: wady serca (5 przypadków), choroby dietozależne (5 przypadków, w tym 3 przypadki cukrzycy i jeden celiakii) czy odwapnienie kości (4 przypadki). Jest to tylko hipoteza - aby ją zweryfikować, należałoby przeprowadzić szczegółowe badania na znacznie większej grupie pacjentek. Możemy zauważyć konieczność dbania o higienę psychiczną i prowadzenia regularnej kontroli poziomu hormonów tarczycy u kobiet z ZT w każdym wieku. Również istotne jest badanie słuchu i wzroku oraz zapewnienie odpowiedniego sprzętu (uważnie dobrane okulary, soczewki, aparaty słuchowe i akcesoria wspomagające słyszenie) pacjentkom z niedosłuchem i niedowidzeniem.

Czy wzrost i stan zdrowia wpływa na karierę edukacyjną i zawodową kobiet z ZT? Ponad połowa ankietowanych stwierdziła, że ich stan zdrowia miał negatywny wpływ na ich karierę edukacyjną i zawodową. Tylko 3 ankietowane uważają, że ich wzrost negatywnie wpłynął 
na ich edukację. Niski wzrost wpłynął negatywnie na karierę zawodową pięciu badanych kobiet.

Tabela 2. Wpływ stanu zdrowia i wzrostu na karierę badanych

\begin{tabular}{lccc} 
& Zgadzam się & $\begin{array}{c}\text { Nie zgadzam } \\
\text { się }\end{array}$ & $\begin{array}{c}\text { Nie mam } \\
\text { zdania }\end{array}$ \\
$\begin{array}{l}\text { Mój wzrost miał } \\
\text { negatywny wpływ } \\
\text { na edukację }\end{array}$ & 3 & 8 & 3 \\
$\begin{array}{l}\text { Mój wzrost miał } \\
\text { negatywny wpływ } \\
\text { na karierę }\end{array}$ & 5 & 7 & 2 \\
$\begin{array}{l}\text { Mój stan zdrowia } \\
\text { miał negatywny } \\
\text { wpływ na edukację }\end{array}$ & 8 & 4 & 2 \\
$\begin{array}{l}\text { Mój stan zdrowia } \\
\text { miał negatywny } \\
\text { wpływ na karierę }\end{array}$ & 8 & 5 & 1 \\
\hline
\end{tabular}

Źródło: opracowanie własne na podstawie wyników ankiety

Zauważamy, że choroby towarzyszące są większym utrudnieniem dla kobiet z ZT niż niskorosłość. Nie znaczy to, niestety, że wzrost nie ma wpływu na możliwość zatrudnienia. Warto w tym miejscu przytoczyć treść wiadomości, jaką jedna z uczestniczek doświadczająca niskorosłości (wzrost poniżej $140 \mathrm{~cm}$ ) przesłała po wypełnieniu ankiety.

Mam 51 lat i mam Zespół Turnera. Nie byłam leczona hormonem wzrostu. Mój wzrost to $136 \mathrm{~cm}$. Jestem po filologii rosyjskiej. Pracowałam w księgowości, bo mam taki kurs - praca w sam raz dla mnie. Niestety, przyszła prywatyzacja i zaraz likwidacja. Byłam na bezrobotnym. Szukałam pracy, ale ze względu na mój wzrost nikt nie chciał mnie przyjąć. Często słyszałam: jest Pani za mała, gdybyśmy wiedzieli, to byśmy do Pani nie dzwonili (na rozmowę o pracę). Udało mi się dostać pracę na umowę zlecenie - sprzątanie. Ale po jakimś czasie zwolnili nas, bo zatrudnili studentów. Znów na bezrobotnym. Dzięki 
znajomości pracowałam rok w księgowości na zastępstwo za kobietę na urlopie macierzyńskim, a potem wróciła do pracy ta kobieta i znów byłam na bezrobotnym. Szukałam pracy, ale nie chcieli mnie w sklepie, na kasie, na magazynie i w innych miejscach. Nawet na mycie garów w stołówce nie chcieli mnie, bo jestem za mała. W końcu pracuję znowu jako sprzątaczka, ale na umowę o pracę. Starałam się o rentę, ale ZUS odmówił. [...] Będę znowu starać się o rentę, choć wiem, że nie mam szans. Niepełnosprawność mam w stopniu lekkim, wywalczoną sądownie ${ }^{15}$.

\section{Podsumowanie}

Ankieta przeprowadzona na grupie 14 pacjentek, choć nie może stanowić podstawy do uogólnień, pozwala na dokonanie pewnych obserwacji i postawienie hipotez. Kobiety z ZT pomimo wielu problemów zdrowotnych osiągają wyższe wykształcenie i podejmują pracę zawodową. Utrudnienia w zdobyciu wymarzonego zawodu mogą wynikać m. in. z niskorosłości, niedosłuchu, słabego zdrowia, pesymistycznej i biernej postawy wynikającej z zaburzeń nastroju lub też niechęci pracodawców do zatrudnienia osób z niepełnosprawnością.

Trudnościom tym można zapobiegać na kilka sposobów. Wprowadzenie terapii hormonem wzrostu w odpowiednim okresie życia pozwala dziewczętom z ZT osiągnąć wzrost zbliżony do wzrostu kobiet zdrowych, co wraz z suplementacją wapnia i opieką ortopedyczną zapobiega powstawaniu niepełnosprawności z tytułu niskorosłości lub chorób układu kostnego. Profilaktyka zapalenia ucha środkowego wraz z opieką laryngologiczną i audiologiczną pomoże zapobiec uszkodzeniom słuchu lub zmniejszyć ich skutki. Niezwykle ważna jest także odpowiednia higiena psychiczna. Rodziny, które usłyszały diagnozę, warto objąć specjalistyczną opieką psychologiczną, oferując zarówno chorującej córce, jak i jej bliskim zajęcia z zakresu psychoedukacji, kształtowania wizerunku i pozytywnego obrazu własnego ciała, autoprezentacji, technik radzenia sobie ze stresem, doradztwa zawodowego oraz życia seksualnego i rodzinnego osób z niepełno-

15 Wypowiedź ankietowanej nr 5. 
Katarzyna Waliczek - Kobieta z zespołem Turnera...

sprawnością (ze szczególnym naciskiem na przygotowanie do małżeństwa i adopcji). W razie zaistnienia poważniejszych problemów należy zapewnić zajęcia terapeutyczne oraz konsultację $\mathrm{w}$ poradni zdrowia psychicznego. Podkreślmy, że podstawę działań na rzecz zdrowia psychicznego powinny stanowić takie zasady, jak dostępność, dobrowolność, poszanowanie prywatności oraz profesjonalizm.

Ważne jest także zadbanie o dobre praktyki w miejscu pracy dla tych kobiet, które już nabyły niepełnosprawność. W przypadku kobiet z niskorosłością konieczne będzie dostosowanie miejsca pracy oraz wszystkich sprzętów do potrzeb osoby o wzroście poniżej 150 czy $140 \mathrm{~cm}$. Pacjentki niedosłyszące, oprócz starannie i indywidualnie dobranych aparatów słuchowych i niezbędnych akcesoriów ułatwiających słyszenie (na przykład urządzenie Bluetooth, umożliwiające podłączenie aparatów do smartfona, suszarka do aparatów czy zestaw ochronny zabezpieczający aparat przed zawilgoceniem), potrzebują środowiska pracy o odpowiedniej akustyce. Kobiety chorujące przewlekle mogą wymagać m.in. dostosowania warunków i czasu pracy do wydolności organizmu (na przykład przy wadzie serca) oraz prowadzonego stylu życia (na przykład przy cukrzycy).

Z punktu widzenia pracodawcy sprawą ważną będzie fakt posiadania przez pracownicę orzeczenia o niepełnosprawności. Orzeczenie posiadane przez pewną część pracowników pozwala uniknąć firmie opłacania składek na rzecz PFRON oraz uzyskać ewentualne dofinansowanie na stworzenie miejsca pracy. Może mieć to wpływ na uzyskanie zatrudnienia. Wydaje się więc zasadne informowanie pacjentek o możliwości ubiegania się o orzeczenie i o korzyściach płynących $\mathrm{z}$ jego uzyskania. Równie istotne będzie kształtowanie dobrych praktyk w komisjach PFRON (pozytywna postawa wobec ubiegających się o orzeczenie, dążenie do ułatwienia całej procedury i tym podobne). 


\section{Bibliografia:}

Jeż W. i in., Zespół Turnera, Termedia Wydawnictwa Medyczne, Poznań 2010.

Little People of America, FAQ, http://www.lpaonline.org/faq-\#Operation, [dostęp: 14-04-2018].

Łącka K., Zespół Turnera - korelacja między kariotypem a fenotypem, „Endokrynologia Polska 2005, Tom 56, Nr 6.

Rovet J., Turner Syndrome: a Review of Genetic and Hormonal Influences on Neuropsychological Functioning, „Child Neuropsychology” 2004, Vol. 10 No 4.

Świątkiewicz-Mośny M., Tożsamość napiętnowana. Socjologiczne studium mechanizmów stygmatyzacji i autostygmatyzacji na przykładzie kobiet z zespołem Turnera, Nomos 2010.

Tabelka z danymi MZ opublikowana przez Fundację Pro, http://stopaborcji.pl /dane-z-ministerstwa-zdrowia-potwierdzaja-ponad-37-aborcji-to-dzieciz-zespolem-downa/; [dostęp: 14-04-2018].

Zadrożna I., Social Functioning of Women with Turner Syndrome. Research \& Discussion, „Interdyscyplinarne Konteksty Pedagogiki Specjalnej” 2013, nr 1.

Zadrożna I., Zespół Turnera [w:] M. Buchnat i K. Pawelczak (red.), Nieznane? Poznane. Zaburzenia rozwojowe u dzieci z rzadkimi zaburzeniami genetycznymi i wadami wrodzonymi, Wyd. UAM, Poznań 2011. 